\title{
A model of forming polylingual speech culture and communicative competence as a condition for teachers' training
}

\author{
O modelo para criar uma cultura de discurso multilíngue e uma \\ competência comunicativa como a condição de formação de pedagogos
}

\section{EL modelo de formación de la cultura de habla multilingüe y de la competencia comunicativa como una condición para la formación de los profesores}

\author{
Sandugash Kairkhanovna Moldabekova1 ${ }^{1}$, Aigul Zhumageldinovna Sakhariyeva ${ }^{2}$ iD, \\ Kulzhanat Nurymzhanovna Bulatbayeva ${ }^{3}$ iD, Dlimbetova Gaini Karekeevna3 ${ }^{3}$, \\ Zhukenova Alma Karisovna ${ }^{1}$ (i)
}

\footnotetext{
${ }^{1}$ Sh.Ualikhanov Kokshetau State University, Kokshetau, Kazakhstan.

${ }^{2}$ S. Toraighyrov Pavlodar State University, Pavlodar, Kazakhstan.

${ }^{3}$ L.N. Gumilyov Eurasian National University, Nur-Sultan, Kazakhstan.
}

Corresponding author:

Sandugash Kairkhanovna Moldabekova

Email: sakonya177@mail.ru

How to cite: Moldabekova, S. K., Sakhariyeva, A. Z., Bulatbayeva, K. N., Dlimbetova, G. K., \& Zhukenova, A. K. (2021). A model of forming polylingual speech culture and communicative competence as a condition for teachers' training. Revista Tempos e Espaços em Educação, 14(33), e15616. http://dx.doi.org/10.20952/revtee.v14i33.15616

\begin{abstract}
The article addresses the issue of development of Kazakh, Russian and English languages in Kazakhstan. For this purpose, the authors give a definition of the types of bilingualism and polylingualism. The paper focuses on the significance of modeling of the educational process, the use of effective methods and technologies, gradual formation of foreign language speech culture and communicative competence. The model of multilingual teachers' training is presented as a combination of motivational-value, content and technological components. In accordance with this, experimental work was conducted in three Kazakh universities. The result of the experiment is a polylingual speech culture and communicative competence of the future teachers within the selected scope of educational material. Another achievement in the experiment is the professional readiness of undergraduates to develop an integrated educational process for the formation of foreign language communicative competence, an ability to apply the concepts of the learning in educational process and justify them in a discussion. In the course of the study, the authors came to a conclusion that future teachers should have an integrated competence: knowledge of a foreign language and linguodidactic skills to plan classes in a foreign language.
\end{abstract}


Keywords: Artificial bilingualism. Communication culture. Natural linguistic environment. Trilingual communicative competence. Trilingual speech culture.

\section{RESUMO}

O artigo analisa o problema de desenvolvimento do trilinguismo no Cazaquistão moderno: o processo da globalização no mundo exige que as línguas cazaque, russa e inglesa desenvolvam. Para estes efeitos, o estatuto de cada idioma, os tipos de bilinguismo e plurilinguismo como as características de situação linguística são definidos. Descreve-se a importância das tais condições pedagógicas, como a modelagem do processo educativo, a utilização de métodos e tecnologias eficazes, a formação gradual de uma cultura estrangeira de discurso e uma competência comunicativa. Os requisitos atuais para o estatuto do inglês, como uma língua necessária na vida do homem moderno, formam o fundamento para o desenvolvimento desta língua baseando nas línguas cazaque e russa, o que reforça o estatuto da língua inglesa no Cazaquistão e determina a estratégia para desenvolver trilinguismo no sistema educativo. Em resolução dos problemas, apresenta-se o modelo da formação plurilingue de um pedagogo como a trindade de componentes motivadores e axiológicos, substanciais e tecnológicos; revela-se o conteúdo de cada um deles. Implementação dos componentes enumerados do modelo tem resultado em formação da cultura bilingue e plurilingue de discurso e competência comunicativa. A cultura de discurso é definida como a realização da cultura de ação discursiva, enquanto a última - como um constituinte de competência comunicativa. Foram realizados os trabalhos experimentais, que deram os resultados positivos durante o teste de ideias em três universidades do Cazaquistão. Assim, os autores são tanto teóricos (autores de ideias pedagógicas) como praticantes que trabalham diretamente em salas de aula. Uma grande realização é não só a cultura trilíngue dos estudantes, mas também a prontidão profissional dos estudantes licenciados para o desenvolvimento de um processo holístico de aprendizagem para que a cultura estrangeira de discurso e a competência comunicativa sejam formadas. Note-se que o Cazaquistão desenvolveu o bilinguismo cazaque-russo e russo-cazaque e, por conseguinte, a ênfase está na ligação do terceiro idioma - inglês. O estudo concluiu que o desenvolvimento de plurilinguismo deve ser cientificamente sólido em formação de pedagogos que não só devem dominar um idioma estrangeiro, mas também ter uma formação linguística e didática em planificação de aulas das disciplinas linguísticas e não linguísticas. As disciplinas linguísticas devem também ser temáticas e orientadas para comunicação nas áreas certas de interação.

Palavras-chave: Ambiente natural de linguagem. Bilinguismo artificial. Competência comunicativa trilíngue. Cultura de comunicação. Cultura trilíngue de discurso.

\section{RESUMEN}

El artículo examina el problema del desarrollo del trilingüismo en contexto del Kazajistán contemporáneo: el proceso de la globalización mundial requiere el desarrollo del kazajo, ruso e inglés. Para estos fines, se ha determinado el estatus de cada una de las lenguas, los tipos de bilingüismo y multilingüismo para caracterizar la situación lingüística. Asimismo, se ha descrito la importancia de la presencia de ciertas condiciones pedagógicas, tales como el modelado del proceso educativo, el uso de métodos y tecnologías eficaces, la formación gradual de una cultura del habla en cuanto a las lenguas extranjeras y de la competencia comunicativa. Como fundamento para el desarrollo del idioma inglés con base en el kazajo y el ruso sirven los requisitos modernos del estatus del inglés como lengua franca, necesaria para una persona hoy en día. Esto fortalece el estatus del inglés en Kazajistán y determina la estrategia para el desarrollo del trilingüismo dentro del sistema educativo. A la hora de resolver las tareas planteadas, se presenta un modelo de formación multilingüe para profesores que tiene tres componentes principales: el de los valores motivacionales, el del contenido y el tecnológico, así se da a conocer en que consisten cada uno de ellos. Como resultado de la implementación de los componentes del modelo arriba mencionados se 
forma una cultura del habla bilingüe o multilingüe y la competencia comunicativa. La cultura del habla se define como la implementación de la cultura de la comunicación verbal, esta última siendo parte integral de la competencia comunicativa. Se ha llevado a cabo una investigación experimental que dio resultados positivos en el proceso de aprobación de las ideas en tres universidades de Kazajistán. Al mismo tiempo, los autores son tanto los teóricos (autores de las ideas pedagógicas) y como los profesionales que trabajan directamente en las aulas. El logro principal no es solo la cultura trilingüe de los estudiantes, sino también la preparación profesional de los estudiantes de máster para desarrollar un proceso educativo integral en cuanto a la formación de una cultura del habla de lenguas extranjeras y de la competencia comunicativa. Es de señalar que el bilingüismo kazajo/ruso y ruso/kazajo es habitual en el territorio de Kazajistán y, por lo tanto, el énfasis está en agregar el tercer idioma-el inglés. Como resultado de la investigación, se ha concluido que el desarrollo del multilingüismo debe ser un fenómeno científicamente fundamentado durante la formación de los profesores, que no solo deben hablar una lengua extranjera, sino también tener una formación en didáctica de lenguas a la hora de planificar las clases tanto de disciplinas lingüísticas, como no lingüísticas. Las disciplinas lingüísticas también deben ser de naturaleza temática y estar enfocadas en la comunicación en las áreas de comunicación que sean necesarias para los estudiantes.

Palabras clave: Bilingüismo artificial. Competencia comunicativa trilingüe. Cultura de la comunicación. Cultura del habla trilingüe. Entorno natural de comunicación.

\section{INTRODUCTION}

Today, there is a new educational paradigm which does not actually consider English as a "foreign language" but as a prerequisite for "ensuring the involvement of all Europeans in the new knowledge society". In particular, this is evidenced by the documents of the European Commission "framework strategy for multilingualism for improving the effectiveness of language acquisition" (2000) and "New framework strategy for multilingualism" (2005). According to the strategy of multilingualism, Europeans have to acquire "practical skills and abilities in at least two languages other than their native language".

A position proposed by an American linguist of Indian origin $\mathrm{Br}$. Kachru is noteworthy in this regard as it declares the transformation of the English language into a global language of universal communication. Br. Kachru captured the pluricentric profile of the English language in a useful diagram he refers to as the Three Concentric Circles of English. The three circles, including the Inner Circle, the Outer Circle, and the Expanding Circle, "represent three distinct types of speech fellowship of English, phases of the spread of the language, and particular characteristics of the uses of the language and of its acquisition and linguistic innovations" (Kachru, 2006).

According to Kachru, in terms of language acquisition and use, the circles comprise the following: (a) the Inner Circle including those countries where English is spoken as a first or native language (L1) in countries including English-speaking Canada, USA, UK, Australia, and New Zealand; (b) the Outer Circle, represents countries where English is institutionalized as an additional language and learned as a second language (L2) such as Malaysia, Singapore, the Philippines, India, and Kenya; and (c) the Expanding Circle including countries such as Norway, Brazil, China, Korea, and Japan, where English is a foreign language (EFL).

According to Graddol, three partially overlapping circles should be used instead of concentric circles. In his study, Graddol considers it acceptable to use terminology that divides all English speakers into three groups: those who speak it as the first language (L1), those who speak it as the second language (L2), and those who speak English as a foreign language (EFL). Explaining the difference between the categories of speakers of English as a second language and a foreign language, Graddol writes: "the Main difference between a speaker of fluent English as a foreign language and a speaker of English as a second language depends on whether English is used in the 
country and in the family of speakers and thus determines whether it is the language repertoire of his personality" (Graddol, 2000).

Bilingualism is observed in many European countries, with linguistic and educational goals playing an important role. Baker pointed out the importance of linguistic and educational purposes: "First of all, it is necessary to distinguish between education that uses and encourages two languages and education for children of a linguistic minority. This is the difference between a class where learning officially promotes bilingualism and a class in which bilingual children are already present, but the curriculum does not promote bilingualism. Remaining ambiguous and imprecise, the general term "bilingual education" refers to both situations. You can try to achieve accuracy by defining the main types of bilingual education" (Baker, 2006).

With regard to bilingual education, education with natural and artificial bilingualism can be distinguished. An example of a natural language environment are the EU countries, where several Nations can live in one small area (Belgium), as well as the USA, Canada, where there is a very large number of refugees, immigrants, people who come from Latin America and representatives of national minorities.

Artificial bilingualism is caused by entering the global informational and business space, which is impossible without a knowledge of a foreign language. A bright example is the experience of Russia, Kazakhstan, Japan and China, where artificial bilingualism is intensively developing (Khabarova, 2011).

The problem of multilingual education occupies one of the central places in the educational practice of most countries where representatives of different ethnic and religious groups, and different cultural traditions live.

Currently, the processes of integration and internationalization is underway. Internationalization has led to significant changes in universities around the world. International universities are becoming important. Aintzane Doiz, David Lasagabaster \& Juan Manuel Sierra examine the role of language and culture in an international Univesrity, using the example of Basque Country University (Spain). At the same time, the authors pay attention to the influence of English on the attitude to the minority language - Basque (Doiz et al., 2013).

Elizabeth Walker considers the need to combine socio-cultural and systemic-functional linguistic perspectives in the educational process. She addresses the issue of how bilingual educators can plan language learning correctly (Walker, 2010). The authors of the present article consider the point of view on the bilingual training of Mihyon Jeon to be very interesting. The author studies the types of language ideologies, in particular, considers the Korean-American perspective. The ideology regarding the Korean language cannot be separated from the views of Korean people on English language proficiency and Korean immigrants (Jeon, 2009).

Language policy is one of the most important aspects in the economic and social modernization of the Kazakh society. The beginning of the new language policy of independent Kazakhstan was the proposal of the President N. Nazarbayev to begin the phased implementation of the cultural project "Trinity of Languages" (Nazarbayev, 2006).

N. Nazarbayev emphasized in the "Strategy for the Transformation of Society and the Revival of the Eurasian Civilization" that "... Kazakhstan is unique and strong with its multinational population. A unique polycultural space was formed on its land ... The multiculturalism of Kazakhstan is a progressive factor in the development of society. The Eurasian roots of the peoples of Kazakhstan allow us to connect Eastern, Asian, Western, and European streams and create a unique Kazakhstan version of the development of multiculturalism" (Nazarbayev, 2002).

The Concept for the Development of Foreign Language Education of the Republic of Kazakhstan was developed in 2006 (Kazakh Ablai khan University of International Relations and World Languages); the Concept of development of multilingual education in the Republic of 
Kazakhstan was developed in Karaganda State University named after academician E.A. Buketov in 2008.

A single language standard for teaching three languages was adopted in the republic in accordance with the dynamically changing conditions for the development of target languages in the education system. This document is intended to regulate the process of learning target languages. In this case, the language standard is a framework document that defines common boundaries, i.e. the main approaches, principles, and strategies for teaching three target languages (Y. Altynsarin NAE, 2017).

In Kazakhstan, such scientists as B.A Zhetpisbayeva, K.N. Bulatbaeva, K.K. Duisekova, T.V. Mikhailova et al. are engaged in the study of trilingual education.

They believe that the basis of trilingual (multilingual) education should be a properly structured system of teaching (three) target languages, corresponding to the real situation of development of scientific, methodological and methodical base of the Kazakh, Russian and English languages, and appropriate selection of educational material (Zhetpisbayeva, 2017; Bulatbaeva et al., 2018; Syrymbetova, 2017; Ospanova et al., 2020; Duisekova \& Mikhailova, 2018).

The methodology of trilingual education in modern conditions is determined by historical and socio-pedagogical prerequisites: 1 ) the linguistic situation of Soviet Kazakhstan has historically been determined by Russian-Kazakh (not Kazakh-Russian) bilingualism, due to this the scientific and methodological base of teaching Russian as a native and as a non-native language has a high level of maturity; 2) before the independence, the proportion of schools with Russian language of instruction was predominant in Kazakhstan. In these schools, the Kazakh language has not been studied. Such a peripheral location of the Kazakh language has become a limiting factor for the development of its functional activity and triggered a shortage of pedagogical experience in the issues of Kazakh language teaching, including as a non-native language; 3) announcement of the state status of the Kazakh language and the real level of its functional use became an opportunity to increase the amount of training time in the standard curricula, but the lack of theoretical and applied research of linguistic and didactic aspects of the Kazakh language still does not allow to strengthen its scientific and methodological base; 4) the modern linguistic situation is complicated by the fact that the linguistic-communicative space of the Kazakh community with the dominance of the Russian-language actively includes English, which requires studying in the amount necessary for integration into the world economy (Zhetpisbayeva, 2008).

The educational system can contribute to the formation of a trilingual society, which will require: trained teachers and school leaders capable of providing high-quality education in three languages; state and public support; financial investment and time for the implementation of the trilingual education program; the creation of an atmosphere in society that encourages the constant use of all the three languages.

\section{METHODOLOGY}

\section{Research methods}

To identify the requirements for professional training of specialists, an expert analysis of legal documents was carried out: the Law "on Education" of the Republic of Kazakhstan, the Law "On languages of the Republic of Kazakhstan", the President's Address, "Strategy of Kazakhstan 2050", "State program for the development of education of the Republic of Kazakhstan for 20112020", "State program for the development and functioning of languages for 2011-2020", "Roadmap for the development of trilingual education for 2015-2020".

In the course of the present research, the following methods were used: questionnaire, interview, sociological survey, assessment. Students were asked questions related to the topical issues of education: choice of profession, language policy, educational policy, trilingual education, 
and CLIL technology. During the interview with students, the topics related to their potential future teaching activities were discussed: how they passed the pedagogical practice at school, what they learned during this practice, what difficulties they faced and what new skills students gained in terms of practical experience combined with theoretical knowledge.

\section{The experimental basis of the research}

The research involved third-year students of Kokshetau State University named after Sh. Ualikhanov studying in multilingual and English-speaking groups, 3rd and 4th year students of S. Toraighyrov Pavlodar State University, as well as 3rd and 4th year students and 1st year undergraduates of the L. N. Gumilyov Eurasian National University. Students and undergraduates were asked questions related to the educational policy of the introduction of trilingual education in Kazakhstan.

In the analysis of multilingual education issues, the authors of the present article took into account the specifics of the future professional activity of students. The questionnaire was filled out by students of the natural science cycle in the field of "Physics", "Computer Science", "Chemistry" and "Biology" (54 respondents) from Kokshetau and Pavlodar State Universities. The choice of these students is due to the fact that they will teach their subjects in English at school. Among them 23 students study in English-speaking groups (42.59\%) and 33 students study in multilingual groups (61.11\%). From the point of view of gender, the majority of the respondents are girls- 37 (68.51\%) and 17 students are young men (31.48\%). The average age of students is 20 years. The majority of respondents belong to Kazakh nationality (100\%).

The experimental base is also made up of groups of students and undergraduates of the $\mathrm{L}$. N. Gumilyov Eurasian national University, who will have to work in team with non-linguistic specialists-teachers in future and must have sufficient linguodidactic training to provide methodological assistance to teachers.

\section{RESULTS}

The results of the theoretical analysis of normative documents make it possible to state that in accordance with the new educational standards of higher professional education, the primary task of universities in Kazakhstan is the formation and development of certain competencies of students, which are vital for their further successful self-realization in professional and social activities.

The formation of professional competence of a person capable of cooperation, conducting a dialogue, exchanging business information, possessing a communicative business culture, and communicative competence is one of the most important requirements for professional training of a specialist. The success of career growth depends on the ability to establish contact with a partner, on the correct speech behaviour, the ability to adhere to the strategic line in a conversation.

Communicative competence is one of the basic categories of the modern theory and practice of teaching foreign languages and is described in Russian and foreign literature.

Foreign researchers, considering the process of formation of professional communicative competence, primarily paid attention to the linguistic component.

D. Hymes introduced the term "communicative competence" (the concept of communicative competence). He believed that language proficiency implies knowledge of not only grammar and vocabulary, but also of the social conditions of their use. According to D. Hymes, a foreign language communicative competence includes the following sub-competences: grammatical (rules of language); socio-linguistic (rules of dialect speech); discursive (rules of construction of semantic utterance); strategic (rules of maintaining contact with the interlocutor) (Hymes, 1972). 
In the 1980, M. Canale and M. Swain identified 4 main types of competence, which, in interaction with the system of knowledge and skills, form communication. These competencies are: a) grammatical competence: vocabulary, pronunciation, spelling, semantics and sentence formation; b) sociolinguistic competence: correspondence of statements in form and meaning in a specific situation to the context background; c) discursive competence: the ability to initiate and participate in conversations and read sizable written texts; d) strategic competence: compensation by special means for the lack of knowledge of the language, speech and social experience in a foreign language environment (Canale \& Swain, 1980).

Bachman and Palmer (1996), when describing communicative competence, use the term "communicative language activity", which is formed with the following key competencies: a) language/linguistic (the ability to make statements in a foreign language only on the basis of acquired knowledge, understanding language as a system); b) discourse (coherence, logic, organization of speech); c) pragmatic (the ability to convey the communicative content/message in accordance with the social context); d) conversational (the ability to speak coherently, without tension, at a natural pace, without lengthy pauses made to search for the necessary language forms); e) socio-linguistic (the ability to choose language forms); f) strategic (ability to use communicative strategies to compensate for the lack of knowledge in real language communication); g) speech-thinking (readiness to create communicative content as a result of speech-thinking activity: interaction of problems, knowledge and research) (Bachman \& Palmer, 1996).

Bachman's model is valuable in that it considers both language competence and language performance. The model includes not only grammatical knowledge but also knowledge of how to use language in a particular communicative context. 'Communicative Language Ability can be described as consisting of both knowledge, or competence, and the capacity for implementing, or executing that competence in appropriate, contextualized communicative language use' (Bachman, 1996).

For Bachman (1996), communicative competence is composed of two major components: organizational competence and pragmatic competence. Organizational competence is broken down into two parts, grammatical competence and textual competence. Grammatical competence comprises knowledge of vocabulary, syntax, morphology and phonology/graphology. Textual competence involves 'the knowledge of the conventions for joining utterances together to form a text, which is essentially a unit of language - spoken or written - consisting of two or more utterances or sentences' (Bachman, 1990).

Pragmatic competence is composed of two sub-parts: illocutionary competence and sociolinguistic competence. Bachman lists four language functions as part of illocutionary competence: ideational (the way we convey meanings and experiences), manipulative (using language in an instrumental way to achieve ends), heuristic (the use of language to discover new things about our world and solving problems), and the imaginative function (using language beyond the 'here and now' (e.g. for humour or fantasy).

The second part of pragmatic competence is sociolinguistic competence. Sociolinguistic competence is sensitivity to the context where language is used, ensuring that language is appropriate to the person or the situation. This may entail sensitivity to differences in local geographical dialect, sensitivity to differences in register. Sociolinguistic competence also refers to sensitivity to speaking in a native-like or natural way.

French linguist $\mathrm{S}$. Savignon defined communicative competence as "the ability to function in a real communication environment, that is, in a dynamic exchange of information, where linguistic competence must adapt to the reception of extensive information (both linguistic and paralinguistic) from one or more interlocutors" (Savignon, 2002). 
The model of communicative competence, offered by Savignon is presented in the form of "inverted pyramid". This model includes grammatical, discourse, strategic and sociocultural competences. At the same time, the language learner gradually expands his / her communicative competence through practice and experience in an ever-increasing range of communicative contexts and events.

The phenomenon of communicative competence of a specialist has been studied by such Russian scientists as T.V. Beloglazova, L.K. Salnaya and others. They consider that for successful profession-focused communication, including foreign language, students need to have a sufficient level of communicative competence (in foreign language) (Beloglazova, 2006; Salnaya, 2007). The level of proficiency and possession of communicative skills in a foreign language (English) represent the communicative competence of a specialist.

According to L.A. Petrovskaya, communicative competence is characterized by knowledge of the methods of communication, fluency in verbal and non-verbal means of communication. Yu. N. Emelyanova believes that communicative competence is the ability of a person to adapt to social groups and situations, to perform various social roles, to be fluent in verbal and non-verbal means of communication (Aleevskaya, 2016).

A. Zh. Makhmudova believes that "teaching a foreign language should be based on the native language, thus raising both the native language and the foreign language to the highest level in terms of awareness of language forms, generalization of language phenomena, and this thesis can be extrapolated to the situation of the formation of a polylingual personality" (Makhmudova, 2011). The study of the experience of interaction between different languages still retains its theoretical and applied significance, especially in terms of ensuring the greatest effectiveness of the formation of communicative foreign language competence.

Communicative foreign language competence is interpreted as the ability of students to use the means of a foreign language to solve communication problems in the educational field, everyday usage, cultural and industrial spheres; the ability to use language and speech facts to implement the goals of communication. From a psychological point of view, communicative competence is the ability of the speaker to organize his/her activities in its productive and receptive forms in accordance with the situation of communication.

In the present research, the authors defined the readiness of the expert for foreign-language communication, namely evaluated the degree of formation of the main components necessary for foreign language communication. At the same time, the authors especially focused their attention on the motivational component (value orientations, interests, motives), cognitive (foreign-language knowledge) and operational (communicative abilities).

S. A. Nurmukhambetova in her dissertation work titled "Formation of communicative readiness to mastering a foreign language in students of non-linguistic specialties" reveals the content of the concept "communicative readiness to mastering a foreign language". The content of this concept is considered through the rationale of its main components - motivational, emotionalvalue, cognitive, activity and personal.

Let us consider the component composition in more detail: a) motivational component concerns the readiness of a personality to display communicative creativity in the process of intercultural communication; setting on intercultural value orientations (mutual perception, mutual understanding, complementarity, individual autonomy); the desire to productively interact with representatives of foreign cultures; the need for self-realization and self-development; $b$ ) emotional-value component includes the ability to empathy, self-control, reflection, the ability to emotionally respond to the state of communication partners, the level of the general culture, the development of a positive attitude to the study of a foreign language; c) cognitive component determines the knowledge of the patterns of interpersonal interaction, the ability to feel at ease in various situations of communication, mastery of the initiative in communication, knowledge of 
communication norms and rules, skills to correlate the communication situation and the totality of language tools that serve it, that is, the norms of speech culture, the ability to overcome communicative difficulties; d) activity component is determined by the diversity of communicative skills and abilities, ways of behaviour in communicative interaction, manifestation of activity, the ability of the personality to manage their own communicative state, the ability to operate with the norms of speech culture; e) personal component includes the system of individual attitudes in the field of interpersonal communication, the communicative properties of the personality, which characterize the person's need for communication, the attitude to the way of communication, compliance with communication etiquette (Nurmukhambetova, 2017).

Communicative readiness to mastering a foreign language integrates psychological readiness, i.e. the focus on communication, theoretical readiness in the form of the necessary amount of knowledge and practical readiness, represented in the formation of communication skills, the ability to overcome communication difficulties in mastering a foreign language.

During the survey, the authors touched upon issues related to communicative readiness to master a foreign language. In addition, part of the issues was related to the educational trajectory of students and language policy in the teaching of major subjects in English.

One of the questions referred to language policy in the education system of Kazakhstan. Most of respondents, namely, students majoring in "Physics" (93.75\%), students "Computer Science" (86.67\%), "Chemistry" (100\%), and "Biology" (90.91\%) support the policy of trilingual education in Kazakhstan. A small number of students, in particular students majoring in "Computer Science" (13.33\%) and "Biology" (9.09\%) find it difficult to answer the question and only one student majoring in "Physics" (6.25\%) answered negatively (Figure 1).

Figure 1. Results of a survey on trilingual education.

Do you approve of the idea of trilingual education in Kazakhstan?

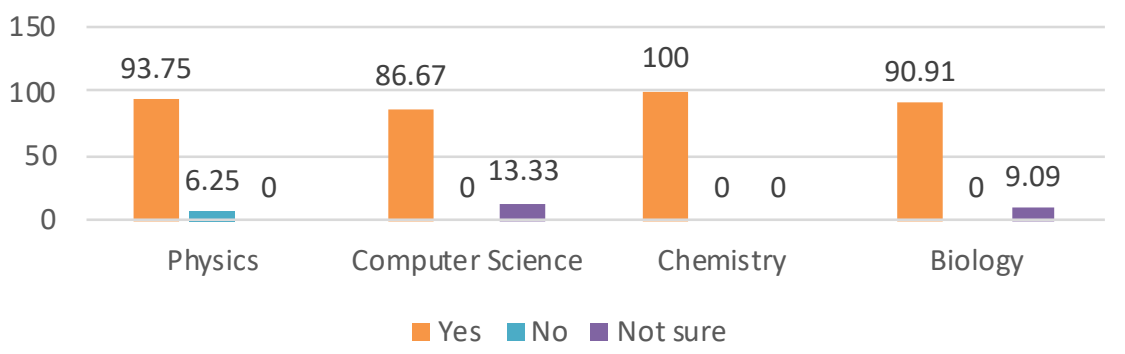

Since the content and quality of education results in the degree of preparedness of students for the taught disciplines, the authors put the respondents the following question: "Are you ready to teach your subject in English at school?"

Based on the answers of students, it is possible to tell that students note a certain dissatisfaction with the level of readiness to teaching a subject in English. For example, students majoring in "Chemistry" (50\%), "Computer Science" (33.33\%), "Physics" (31.25\%), and "Biology" (18.18\%) note slight difficulties in teaching their subject in a foreign language. The possible reasons for dissatisfaction of students in the level of proficiency in English can be different: inefficient methods of teaching, low motivation of students, lack of the language environment, etc. (Figure 2). 
Figure 2. Results of the survey on the level of teaching in English.

Readiness to teach the subject in English

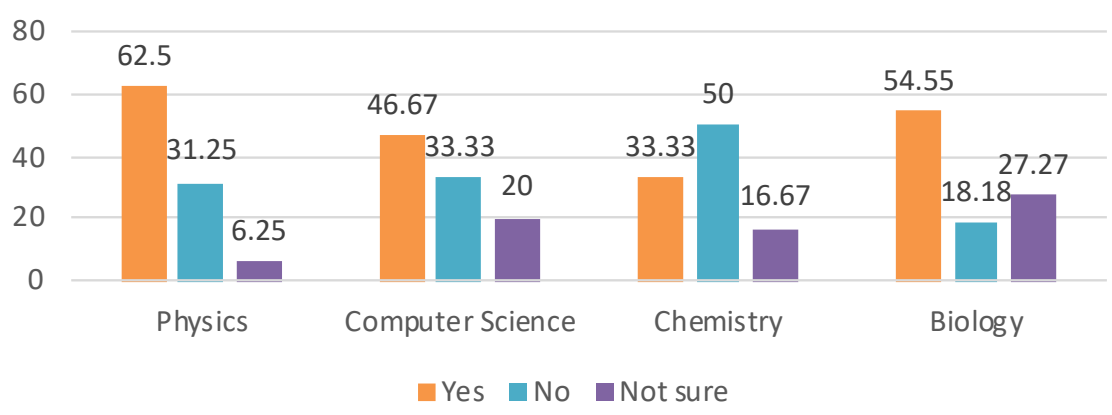

The answers of the students to the question "Is the chosen profession of a teacher interesting for you?" were interesting. Future teachers majoring in "Biology" show a positive interest in their chosen profession. Students majoring in "Physics" are also pleased with the choice of their future profession. Students majoring in "Computer Science" and "Chemistry" show enthusiasm for the chosen profession (Figure 3).

Figure 3. Results of a survey on the choice of a teacher's profession.

Interest in the profession

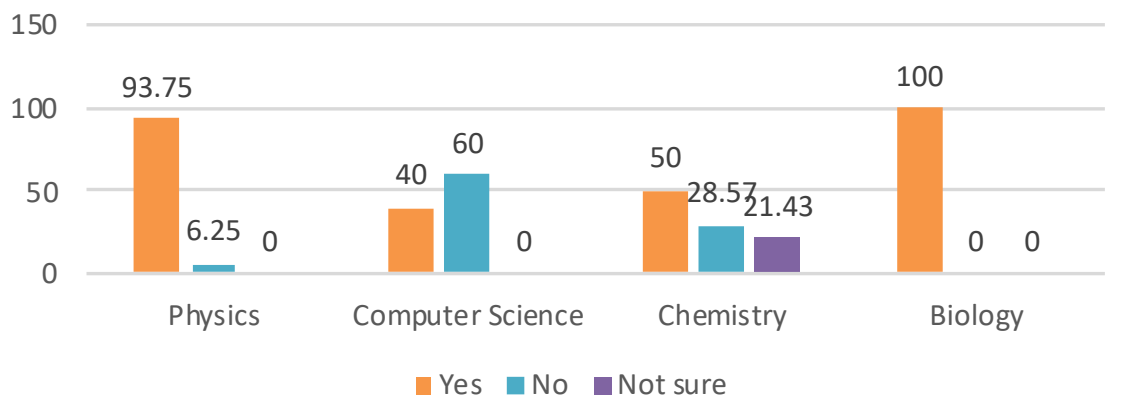

The next question in the survey was related to the knowledge and application of CLIL technology in the classroom. The majority of respondents, including students majoring in "Physics" (81.25\%), "Computer Science" (86.67\%), and "Biology" (72.73\%), are aware of the content language integrated learning. However, the answers of students majoring in "Chemistry" are surprising. $58.33 \%$ of students know about CLIL-technology, $33.33 \%$ do not, and $8.33 \%$ find it difficult to answer (Figure 4).

Figure 4. Results of a survey on the knowledge and application of CLIL technology.

\section{Knowledge of CLIL technology}

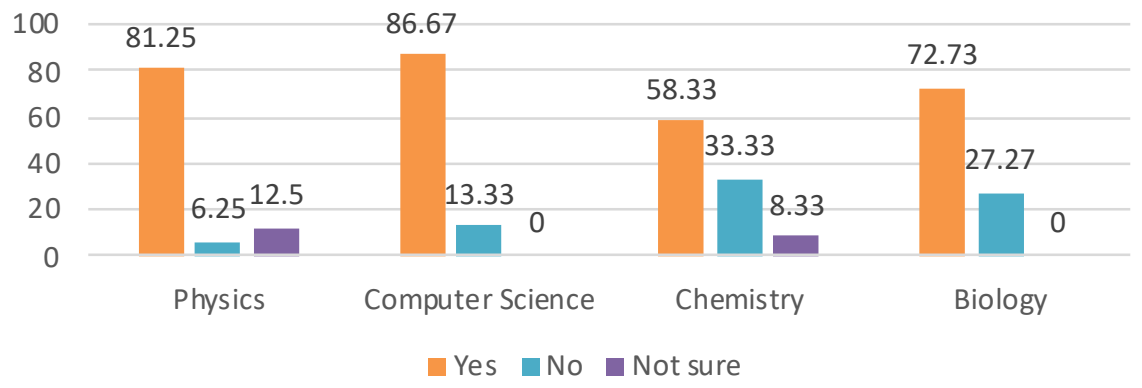


New approaches to teaching a foreign language should ensure the transition from the narrow task of language learning on the example of vocabulary to such broader and multidisciplinary tasks as providing vocational guidance for students and providing students with effective ways to use a foreign language as a means of professional activity and constant personalprofessional self-development.

First, special methodology should be used that will recreate the subject and social contexts of professional activity of future specialists. Second, the success of the professionalization of language training can be ensured by the possibility of personal participation of students in the organization of their own training and professional development, in accordance with their needs and capabilities.

Sufficient awareness for professional methodological assistance was shown by students and undergraduates of the Eurasian National University named after L.N. Gumilyov. At the Department of Foreign Philology, future foreign language specialists (including future teachers of a foreign language) acquire the ability to plan classes in English for non-linguistic disciplines: in the third year they study "Methods of teaching a foreign language", in the fourth year - "Fundamentals of Linguodidactics", and in the first Master's course - "Comparative Linguodidactics." During this period, they learn different technologies for integrating a language and a non-linguistic subject. To do this, subject material is subjected to cognitive processing, then step-by-step actions are planned to achieve foreign communicative competence. This means that the result is the ability of students to communicate on the topic of the discipline in English. At the same time, a mandatory component of the communicative competence is a bilingual and/or trilingual speech culture. Speech culture is formed gradually and in stages. The cognitive component is a bilingual non-linguistic content in biology/chemistry/physics, etc. It is a single cognitive basis that becomes a favourable condition for the formation of a bilingual or polylingual speech culture. At the initial stage, speech culture is formed at the level of lexical skills (correct usage of thesaurus and thesaurus-related vocabulary, syntagmatic expansion of the scope of utterance). Then lexical and grammatical norms of speech culture, synonymy of utterances and their use in communication situations (correspondence) are formed, which strengthens the free and normative use of the second language. On the basis of lexical and grammatical aspects of speech culture, speech and communicative competence is formed. Students and undergraduates showed a sufficient and high level of training in the issue of bilingual formation of speech culture and communicative competence based on environmental topics in biology, chemistry, and computer science. At the same time, the authors have tested in practice the scientific ideas of ecologization of professional education of Author 4 and the possible implementation of cognitive and communicative technology of bilingual education in non-linguistic disciplines of Bulatbaeva (Bulatbaeva et al., 2018). Currently, students and undergraduates are ready to develop author's manuals on this technology for different specialties, which indicates the full implementation of the activity component of training. At the same time, they defined a hierarchical system of exercises for the formation of foreign language speech culture, which are consistently introduced at different stages of training.

\section{DISCUSSION}

According to the "Road map for the development of trilingual education in $2015-2020$ ", it is planned to teach natural science subjects in English in all schools of the country. The interviewed students are future graduates who will teach the disciplines in English. Based on students' responses we can conclude that they realize the importance of the pursued educational policy in the republic. Students objectively assess their readiness to teach in English. At the same time, students of Englishspeaking groups have a much higher level of English than students of multilingual groups. And this fact is obvious, because for students of English-speaking groups all disciplines are taught in English, 
while for students of multilingual groups this amount is at least $30 \%$ of the training cycles of minor and major disciplines.

One of the pedagogical conditions for teaching a discipline in English is the reasonable use of CLIL technology. Using CLIL technology involves learning a subject through a foreign language, and a foreign language through the taught subject. Language learning becomes more focused, as language is used to solve specific communicative tasks. The learner receives a large amount of language material, which implies immersion in the natural language environment. The use of CLIL technology contributes to the formation of proper interpersonal skills, intercultural understanding and language abilities, while correctly using the basic principles of integrated English language and subject learning (Mehisto et al., 2012). The cognitive and communicative technology of bilingual education in non-linguistic disciplines is considered to be effective in Kazakhstan (Bulatbaeva et al., 2018).

For effective preparation of university graduates for professional activity in the context of intercultural interaction, a comprehensive training program should be developed, taking into account interdisciplinary communication and a modular educational program. The image of a future high school teacher also plays an important role.

Thus, the present study made it possible to build a model of multilingual training of a future university teacher, which includes three components: motivational-value, content and technological (Figure 5).

Figure 5. Model of multilingual training of future university teachers.

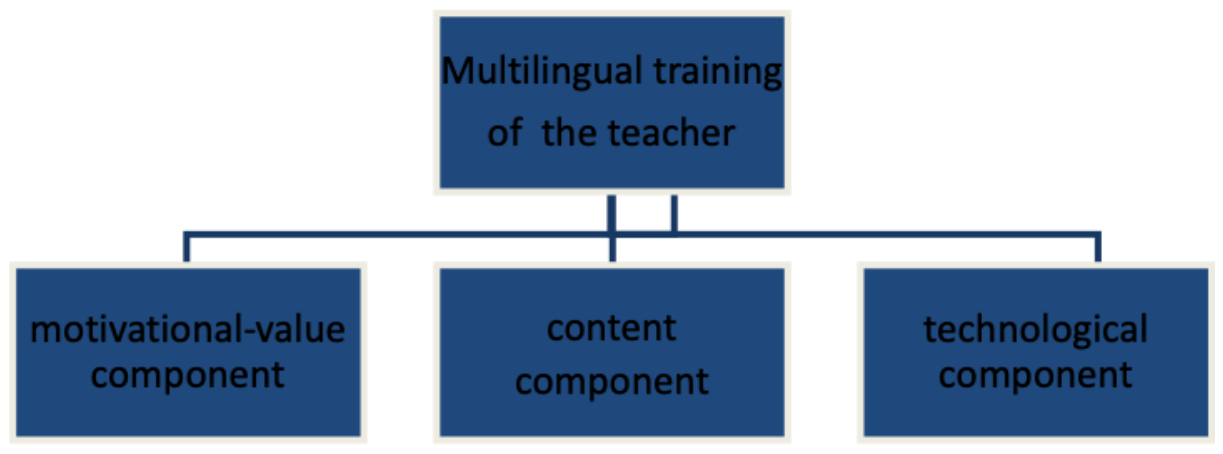

Below is a detailed look at the components of multilingual training of a future teacher:

The motivational-value component represents a system of motivational-value and emotional-volitional relations of students to the world, activity, people, themselves, their abilities, and their development. Motivation for the specific content of the activity is formed through educational and cognitive games, educational discussions, methods of emotional stimulation, etc., which make a student take an active position of the future teacher, master universal ways of cognitive activity, practice critical analysis, selection and design of personality-significant content of activity.

The motivational-value component of students who teach English is actively shown when giving lessons to eco-volunteers who want to know English in order to actively discuss environmental issues. Independent and voluntary planning and giving lessons indicates a conscious approach to solving environmental problems, and civil responsibility for the Earth. At the same time, students choose ecotopics on their own initiative - they present different information in class. For example: undergraduates have chosen environmental topics for their classes.

The content component includes a system of knowledge about nature, society, thinking, technology, methods of activity, the assimilation of which ensures the formation in the minds of students of the scientific picture of the world, provides the students with a dialectical approach to cognitive and practical activities. The content of education is focused on the formation of students' 
readiness for pedagogical activity. The formation of speech culture in the content component is based on the cognitive plan of the intended monologue, when active vocabulary, active semantic structures of utterances, and active communication situations are selected for each micro-topic for the implementation of certain speech tasks.

At present, students understand the importance of acquiring the skills of reading and writing as types of speech activity and communication in a foreign language, as in the modern world a perfect knowledge of professionally focused foreign language is often a factor of career growth. At the same time, the acceptance of the position of the future teacher as being personally significant in the process of professional development, the analysis of the content of the educational system is very significant. For the successful implementation of the educational program, teachers develop curricula based on a competency-based approach using a modular framework; make a clearer selection of training content, as close as possible to real-life communication situations; they use modern information technologies and individual educational trajectories, which are focused primarily on the "integrative development of foreign language communication skills; implement common forms of control and criteria for evaluating linguistic communicative competences in accordance with international standards" (Safronenko, 2016).

The technological component is the readiness and ability of the individual to carry out research activities, based on the application of knowledge in a certain area and research skills to solve problems of theoretical and practical nature. With regard to the formation of speech culture and communicative competence, the necessity of using effective learning technologies has been proved. This is confirmed by an experiment on the ecologization of education, when lessons on environmental issues were given in parallel in two languages for different specialties (Fahrutdinova et al., 2019).

Modern technologies provide an opportunity to improve the quality of education and use study time more efficiently. Modern educational technologies are focused on individualization, the remote nature and diversity of the educational process, academic mobility of students regardless of age and level of education.

The formation of communicative competence in the process of foreign language communication among students can take place in the process of mastering the social roles characteristic of a particular cultural community. Learning roles occurs in interaction, where contact between communicating subjects is a condition and consequence of productive communication. At the same time, it is necessary to pay attention of students to the understanding and conscious use in the process of communication of models of a different culture in order to adequately master them.

\section{CONCLUSION}

Based on the position of the abovementioned researchers in the field of trilingual education, the authors of the present article identify a set of elements in pedagogical professional competence in terms of practical skills of a multilingual teacher:

1. Modern life brings special requirements for teaching and learning foreign languages, so teachers need to make some adjustments to the curriculum of English language, to use effective methods of stimulating cognitive activity of students putting the ultimate goal of the formation of a foreign language communicative competence.

2. The main task of the teacher in teaching a foreign language consists in encouraging students for meaningful interaction for the successful development of the program of subjectintegrated learning. Tasks should be designed in such a way that the learners have a reason or purpose for speaking connected with real life.

3. The formation of bilingual and trilingual communicative competence demands an accurate sequence of receptive and productive exercises. The quantity and the sequence of exercises of 
trainees will vary depending on complexity of the studied subject. The form of expression of thoughts and a way of their specification depend on the language level of trainees. For the solution of communicative tasks special attention should be paid to the dynamics of work both individually and in groups of several people. An undoubted indicator of the development of multilingualism is the aspect of ownership of speech culture when using different languages. This is based on the principle of parallel representation of language material on a functional and semantic basis.

4. Knowledge of a foreign language, in particular English, is necessary especially in the modern world due to the expansion of professional contacts, a freer exchange of information, the growth of the amount of scientific and educational literature in English as it is considered the international language for scientific publications.

5. One of the pedagogical conditions of teaching a discipline in English is a reasonable application of CLIL technology. Studying of language becomes more purposeful as language is used for the solution of specific communicative tasks. Use of CLIL technology promote formation of the correct skills of interpersonal communication, cross-cultural mutual understanding and language abilities at competent use of the basic principles of the integrated training in English and nonlinguistic subjects.

6. The formation of communicative competence should be considered by means of communicative readiness for intercultural communication. At the same time, communicative readiness to master a foreign language involves the use of its main components - motivational, emotional-value, cognitive, activity and personal.

7. The authors of the present article believe that communicative readiness to master a foreign language is a part of the general professional readiness of a specialist and represents a complex professionally significant quality of a person, including a focus on professional intercultural communication, language knowledge and communication skills.

Authors' Contributions: Moldabekova, S. K.: conception and design, acquisition of data, analysis and interpretation of data, and drafting the article; Sakhariyeva, A. Z.: conception and design, acquisition of data, analysis and interpretation of data, and drafting the article; Bulatbayeva, K. N.: analysis and interpretation of data, and critical review of important intellectual content; Dlimbetova, G. K.: analysis and interpretation of data, and critical review of important intellectual content; Zhukenova, A. K.: analysis and interpretation of data, and critical review of important intellectual content. All authors have read and approved the final version of the manuscript.

Ethics Approval: Not applicable.

Acknowledgments: Not applicable.

\section{REFERENCES}

A New Framework Strategy for Multilingualism (2005). COM final. Brussels.

Aleevskaya, Yu. I., Ashirbagina, N. L., \& Meshcheryakova, N. A. (2016). Educational competence as a subject of pedagogical research. Integraciya obrazovaniya, 20(3).

Bachman, L. F., \& Palmer, A. S. (1996). Language Testing in Practice: Designing and Developing Useful Language Tests. Oxford etc.: OUP.

Baker, C. (2006). Foundations of Bilingual education and Bilingualism. Clevedon: Multilingual Matters.

Beloglazova, T. V. (2006). Foreign language communication in the process of forming the linguistic and humanitarian culture of students of non-linguistic specialties: PhD Dissertation: 13.00.08. Surgut.

Blanche, P. (1994). Is the International Language "Broken English"? Research Reports of Kochi University, Humanities 43, 1-14.

Bulatbaeva, K. N., Fahrutdinova, G. Z., Dlimbetova, G. K., Moldabekova, S. K., \& Bakirova, K. Sh. (2019). Ecological Problems of the Region as the Base for Foundation of an English-Speaking Communicative Competence. V International Forum on Teacher Education. Proceedings IFTE-2019. 
Bulatbaeva, K. N., Dlimbetova, G. K., \& Fahrutdinova, G. (2018). Cogitive-Communicative Technology Of Bilingual Education As Condition Of Formation Of Ecological Competence. European Proceedings of Social and Behavioral Sciences Journal, 185-192.

Canale, M., \& Swain, M. (1980). Theoretical bases of communicative approaches to second language teaching and testing. Applied Linguistics, 1(1), 1-47.

Conception of development of multilingual education in the Republic of Kazakhstan.

Dlimbetova, G. K., \& Moldabekova, S. K. (2018). On the principles of subject-language integrated learning in the context of multilingual education. Materials of the international scientific and practical conference "Psychological and pedagogical research in modern education". RUDN (Peoples' Friendship University of Russia).

Doiz, A., Lasagabaster, D., \& Sierra, J. M. (2013). What does 'international university' mean at a European bilingual university? The role of languages and culture. Language Awareness, 23(1-2), 172-186.

https://doi.org/10.1080/09658416.2013.863895

D'yachenko, M. I., Kandybovich, L. A., \& Ponomarenko, V. A. (1985). Readiness to work in stressful situations. Pedagogical aspect. Minsk.

Education \& Training 2010: Work program adopted by the European Commission in 2001 (2005). ETUCE Circular.

Graddol, D. (2000). The Future of English? A guide to forecasting the popularity of the English language in the 21st century. London: The British Council. https://doi.org/10.1111/lang.12341

Hymes, D. (1972). On communicative competence. In J.Pride \& J.Holmes (Eds.) Sociolinguistics. Harmondsworth, England: Penguin Books.

Jeon, M. (2009). Language Ideologies and Bilingual Education: A Korean-American Perspective. Language Awareness, 16(2), 114-130. https://doi.org/10.2167/la369.0

Kachru, B. B. (2006). The English language in the outer circle. World Englishes, 3, 241-255.

Khabarova, L. P. (2011). Foreign language communication in the process of forming the linguistic and humanitarian culture of students of non-linguistic specialties. Bilingual education in higher school. Bulletin of PGPU (Penza State Pedagogical University) named after V.G. Belinsky, 24, 846-852.

Kunanbayeva, S. S., Karmysova, M. K., \& Ivanova, A. M. (2006). Concept of development of foreign language education in the Republic of Kazakhstan. Retrieved from: http://gigabaza.ru/doc/62326.html

Law "On Education" of the Republic of Kazakhstan dated July 27, 2007 No. 319-III. Retrieved from: http://adilet.zan.kz/rus/docs/Z070000319_

Law of the Republic of Kazakhstan No. 151-I of 11 July 1997 on languages in the Republic of Kazakhstan. Retrieved from: https://online.zakon.kz/Document/?doc_id=1008034

Makhmudova, A. Zh. (2011). Interference and transfer in teaching foreign languages in the conditions of subordinative triglossia of secondary school students of the Republic of Dagestan. Materials of scientific and methodological readings of Pyatigorsk state linguistic University, IX, 74-79.

Mehisto, P., Marsh, D., \& Frigols, M. J. (2012). Uncovering CLIL. Content and Language Integrated Learning in Bilingual and Multilingual Education. Oxford, Macmillan Education Publ.

Message of the President of the Republic of Kazakhstan N.A. Nazarbayev to the Citizens of Kazakhstan. Strategy "Kazakhstan-2050": New political direction of the state (2012). Retrieved from: http://www.akorda.kz/ru/official_documents/strategies_and_programs.

Mikhailova, T. V., Duisekova, K. K. (2018). Current state and perspectives of Foreign language education development at Shokan Ualikhanov Kokshetau State University (non-linguistic specialties). Materials of the Vth International scientific conference «Foreign language education: experience, innovations and prospects», Nov. 12-13. Almaty, Kazakh Ablai Khan University of International Relations and World Languages.

National Academy of Education named after Y. Altynsarin (2017). Common standard of three language education. NAO.

Nazarbaev, N. A. (2002). Strategy of society transformation and Eurasia civilization recreation. EHkonomika, 520.

Nazarbaev, N. A. (2007). New Kazakhstan in the new world. Kazahstanskaya Pravda, 33(25278). 
Nurmuhambetova, S. A. (2017). Communicative readiness of non-linguistic students for foreign language usage. PhD dissertation. Astrahan'.

Ospanova, Zh., Tolybayeva, K., Nurkenova, S. K., Duisekova, K. K. \& Baltabayeva, G. (n.d.) Lingua and culture study research on indirect communication cognitive metaphor. Xlinguae. European Scientific Language Journal, 157-165.

Roadmap for the development of trilingual education for 2015-2020. Retrieved from: https://online.zakon.kz/Document/?doc id=35182262\#pos=0;0

Silva, L. R., Santos, A. R., \& Santos, I. T. R. (2020). Public policies for education of/in the field and the school environment in a settlement of the MST: the intimate relationship with the pedagogical policy. Journal of Research and Knowledge Spreading, 1(1), e11737.

Walker, E. (2010). A systemic functional contribution to planning academic genre teaching in a bilingual education context. Language Awareness, 19(2), 73-87. https://doi.org/10.1080/09658410903431721

Received: 16 March 2021 | Accepted: 22 April 2021 | Published: 1 May 2021

This is an Open Access article distributed under the terms of the Creative Commons Attribution License, which permits unrestricted use, distribution, and reproduction in any medium, provided the original work is properly cited. 